\title{
Life on the brink: social stress, trauma and psychopathology
}

\author{
Frankova Iryna ${ }^{1 \mathrm{a}}$ \\ ${ }^{a}$ Bogomolets National Medical University, Kyiv, Ukraine
}

\begin{abstract}
Background. Lifetime most people inevitably will be faced with stress. Life adverse events represent a major risk factor for mental disorders. The stress response promotes adaptive plasticity, or can become maladaptive and harmful, when the response is dysregulated, it depends on susceptibility. Thus, stress-related disorders become a real challenge in the development of treatment strategies.
\end{abstract}

Methods. This review is based on materials of the 29th European college of neuropsychopharmacology congress (September 2016, Vienna), the participants of the "Eastern European Academy of the World Psychiatric Association" and "Servier"company specifically for psychiatric journals of WPA Zone 10 (East European Educational WPA-Servier Academy-"EEE WPA-Servier Academy". The review will present materials from several symposiums: "Life on the brink: stress and psychopathology", "Novel strategies towards targeted interventions in PTSD".

Results. As result, we anticipate that this review will promote knowledge about high quality standards of treatment and evidence-based researches regarding stress-related disorders and distribute them among the modern community of mental health experts.

Conclusion. The stress impact occurs in multiple dimensions simultaneously. Understanding the interaction between stress, the brain and social behavior pave the way to the development of future treatment strategies. In addition, intervention can have different windows of opportunity, the same intervention can heal or harm, depending on the time of appointment.

Keywords: European College of Neuropsychopharmacology Congress, stress, post-traumatic stress disorder, neuronal function, neuroendocrine disorders, PTSD

\section{1. Актуальність}

Даний огляд підготовлений за матеріалами 29-го Конгресу Європейської колегії нейропсихофармакології (вересень 2016 року, Відень, Австрія) учасниками проекту «Східноєвропейська академія Всесвітньої психіатричної асоціації» і компанії «Серв'є» спеціально для психіатричних журналів Зони 10 ВПА (East European Educational WPA-Servier Academy - «EEE WPA-Servier Academy»).

Більшість людей час від часу неминуче стикаються зі стресом. Несприятливі події являють собою серйозну загрозу для психічного здоров'я. Реакція на стрес може сприяти адаптивній пластичності, покращуючи когні-

${ }^{1}$ (C) Frankova I., 2017. This article is distributed under the terms of the Creative Commons Attribution License, which permits unrestricted use and redistribution provided that the original author and source are credited. тивну сферу, якщо фізіологічна реакція на стрес ефективно активується і своєчасно деактивується. У разі дисрегуляції, стрес призводить до неадекватного і шкідливого ефекту, виникнення дезадаптації і психопатології. Актуальність теми стресу в наші дні не залишає сумнівів, на 29 конгресі Європейської колегії нейропсихофармакології стресу було присвячено чотири симпозіуми і одна пленарна лекція, матеріали з двох симпозіумів детально представлені в даному огляді.

\section{2. Стрес і антидепресанти}

В рамках симпозіуму «Життя на межі: соціальний стрес і психопатологія» свою доповідь представляв Maurizio Popoli з інституту Мілана, Італія (лабораторія нейропсихофармакології і функціональної нейрогеноміки). Він почав з базових концепцій, сформульованих ще в 1930 році Гансом Сельє: «Стрес - це неспецифічна відповідь тіла на будь-яку вимогу з боку оточую- 
Рис. 1: Розлади пов'язані зі стресом.

\begin{tabular}{|c|c|c|c|}
\hline $\begin{array}{l}\text { Психічні } \\
\text { розлади }\end{array}$ & $\begin{array}{c}\text { Нейро- } \\
\text { дегенеративні } \\
\text { розлади }\end{array}$ & $\begin{array}{c}\text { Кардіо/церебро } \\
\text { васкулярні } \\
\text { розлади }\end{array}$ & $\begin{array}{c}\text { Метаболічні } \\
\text { розлади }\end{array}$ \\
\hline $\begin{array}{l}\text { - депресія } \\
\text { - тривожні } \\
\text { розлади } \\
\text { - ПТСР } \\
\text { - шизофренія } \\
\text { - розлади } \\
\text { харчової } \\
\text { поведінки } \\
\text { - вживання ПАР }\end{array}$ & $\begin{array}{l}\text { - хвороба } \\
\text { Альцгеймера } \\
\text { • хвороба } \\
\text { Паркінсона } \\
\text { - боковий аміо- } \\
\text { трофічний } \\
\text { склероз }\end{array}$ & $\begin{array}{l}\text { • інфаркт } \\
\text { міокарда } \\
\text { - коронарна } \\
\text { хвороба серця } \\
\text { - інсульт }\end{array}$ & $\begin{array}{l}\text { • ожиріння } \\
\text { • метаболічний } \\
\text { синдром } \\
\text { • діабет II типу }\end{array}$ \\
\hline
\end{tabular}

Список розладів з доведеним зв'язком із стресом.

Рис. 2: Тип відповіді на стрес.

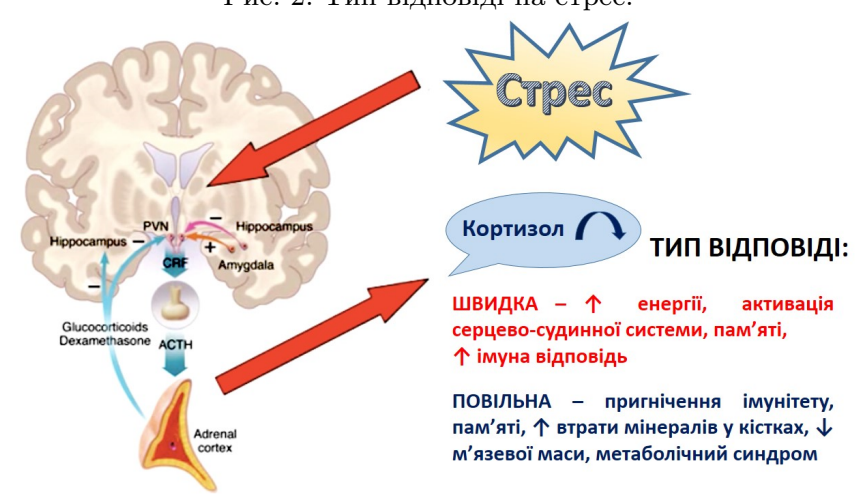

Повільний та швидкий тип відповіді на стрес.

чого середовища (фізіологічна відповідь мозку і тіла)». Стрес це не те, що трапилося з нами, а те, як ми реагуємо на цю подію. Іншими словами, в повсякденному житті важливо не тільки кількість стресу, з яким ми стикаємось, але і як ми на нього реагуємо, адаптивним або дезадаптивним способом $<1>$. Саме дезадаптація призводить до розладів, пов'язаних зі стресом. Стрес це фактор ризику для багатьох психічних і соматичних захворювань (рис. 1).

Якщо звернутися до фізіології, виділяють два типи відповіді на стрес: швидка і повільна. Завдання швидкої відповіді в першій фазі - збільшити швидкість всіх процесів в організмі, які можуть бути корисні для системи «втечі або боротьби» (більше енергії вивільняється з м'язів, відбувається потужна стимуляція серцево-судинної, імунної системи і пам'яті). Друга фаза, набагато повільніша і може займати години, дні

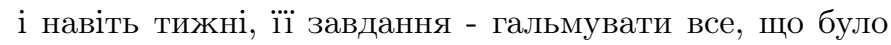
активовано в першій фазі (рис. 2).

Адаптивний спосіб реагування на стрес характеризується своєчасністю зміни швидкого типу відповіді на повільний.

При різних психічних порушеннях і захворюваннях, викликаних стресом, на клітинному рівні змінюється нейронна архітектура, виникає атрофія і стискання апі- кальних дендритів в гіпокампі і префронтальній корі. Це клінічно підтверджує зворотна кореляція між щільністю дендритів, синаптичних шипиків (spines) гіпокампу і виразністю тривоги $/$ депресії $<2>$. Дане дослідження тривало понад 20 років. Виявлена також пряма кореляція між тривалістю депресивного епізоду і зниженням обсягу щільності дендритів в вищезазначених зонах головного мозку $(\Gamma \mathrm{M})<3>$.

Що ж призводить до атрофії дендритів і зниження обсягу нейронів? Гострий стрес викликає активацію гіпоталамо-гіпофізарно-надниркової вісі (ГГНВ), що призводить до підвищення рівня кортикостероїдів. Зв'язуючись із глюкокортикоїдними і мінералокортикоїдними рецепторами, кортикостероїди викликають збільшення кількості глутамату в префронтальній корі $(П Ф К)$ і фронтальній корі $(\Phi K)$, використовуючи механізм, який залежить від фосфориляції синапсину 1 в першу фазу стресу.

Глутамат - це головний медіатор збудження, гаммааміномасляна кислота (ГАМК) - головне гальмо для медіаторів, які проводять збудження в ГМ, ГАМК знаходиться в постійній конкуренції з глутаматом. У нормальному стані ця конкуренція призводить до паритету і тонкої рівноваги між збудженням і гальмуванням в нашому мозку. Гальмування - це не відсутність порушення, а активний процес, що вимагає власних нервових клітин, синапсів, медіаторів. Енергії на гальмування наш мозок витрачає більше, ніж на збудження. ГАМК - це проста молекула, яка синтезується, як це не парадоксально, з глутамату, якщо від нього від'єднати вуглекислий газ. Для того щоб ГАМК працювала саме як медіатор, вона повинна сформуватися в пресинаптичному закінченні аксону. Далі вона виділяється, коли приходить нервовий імпульс, і впливає на рецептори. У ГАМК описано два типи рецепторів, які названі ГАМКА і ГАМКБ-рецептори. І той, і інший обов'язково викликають гальмування. Так відбувається у нормі.

У поєднанні, гострий стрес і кортикостерон впливають дестабілізуюче на глутаматергічну систему, в значній мірі збільшуючи вивільнення глутамату, потенціюючи збудження і синаптичну передачу нервового імпульсу, що призводить до витягування дендритів. Цей феномен, адаптивний при короткочасному впливі стресу, може стати патологічним при хронічному впливі травматичної ситуації $<4>$.

Таким чином, дія стресу в поєднанні з підвищенням рівня кортизолу і порушенням передачі нервового імпульсу в глутаматергічній системі ( $85 \%$ синапсів в ПФК і гіпокампі - глутаматергічні), призводять до змін нейронної архітектури. Якщо за два тижні до експерименту зі стресом призначити антидепресанти (АД), то такого роду реакція глутамату у відповідь на кортикостерон блокується як у швидку, так і в повільну фазу. АД помітно знижують викликане деполяризацією вивільнення глутамату, але не вивільняють ГАМК. Ці дані свідчать про те, що антидепресанти стабілізують нейротрансмісію глутамату в гіпокампі, і являють 
собою корисний інструмент для вивчення взаємозв'язку між функціональними і молекулярними процесами в нервових закінченнях. Схожий вплив на нервову систему викликають регулярні фізичні вправи.

Мауріціо Пополі описав експеримент, що дозволяє відтворити ці дані в експерименті на гризунах. Нещодавно його наукова група показала, що 40-хвилинний протокол впливу гострого стресу (Footshock - удар електричного струму по ногах) швидко посилює викликане деполяризацією вивільнення глутамату і передачу імпульсу в префронтальній і фронтальній корі, за рахунок збільшення циркуляції рівня кортизолу. Зв' язуючись з синаптичними рецепторами, кортизол викликає швидке (не геномне) посилення обороту пресинаптичних везикул з глутаматом в перфорованих синапсах і збільшення розміру пулу готових до викиду (readily releasable pool) везикул, що викликає посилення вивільнення глутамату із синаптичних закінчень. У відповідних дослідженнях було показано, що гострий футшокстрес також різко (на 42,6\%) збільшуе загальну кількість неперфорованих синапсів в ПФК; ефект знову ж частково може бути зменшений попереднім прийомом АД. Ці знахідки є доказом того, що стрес-залежний синаптогенез асиметричних синапсів можна виявити вже через 40 хвилин після початку дії стресу. Крім того, спостерігалася значна атрофія і ремоделювання атипових дендритів в ПФК вже через 24 години після футшок-стресу, що зберігаються протягом 14 днів.

Таким чином, гострий стрес може викликати швидкі структурні / функціональні зміни в глутаматергічних синапсах, а також приводити до стійкого ремоделювання нейронної архітектури.

Вимірювання вивільнення глутамату проводилось в різний час після початку футшок-протоколу (40хв, 2, 6 і 24 ч). Як і очікувалося, рівень кортизолу в сироватці був підвищений в кінці впливу гострого стресу (через 40 хв), але практично повернувся до фізіологічного рівня під час наступних вимірів (через 2, 6 та 24 години) (рис. 3 а). А вивільнення глутамату було посилено весь час, протягом 24 годин, після впливу стресу (рис. 3b). Розмір пулу готових до викиду везикул з глутаматом, який грає важливу роль в підвищенні стресіндукованого вивільнення глутамату в ПФК / $\Phi \mathrm{K}$, був також підвищений протягом 24 годин (рис. 3ㄷ) $<4>$ ).

Попередні дослідження показали, що хронічний стрес викликає атрофію дендритів у гризунів в деяких областях головного мозку; лише кілька досліджень показали аналогічні ефекти після впливу гострого стресу, в основному в гіпокампі. Взяті разом поточні і попередні дослідження показують, що наслідки гострого стресу далеко не тільки гострі. Один епізод стресу, якого неможливо уникнути, може викликати стійке збільшення розміру пулу готових до викиду везикул з глутаматом і посилення вивільнення глутамату в ПФК / ФК протягом принаймні 24 годин, що є основою швидкої відповіді на стрес. Але так само гострий стрес викликає тривалі наслідки і зміни в синаптичних шипиках

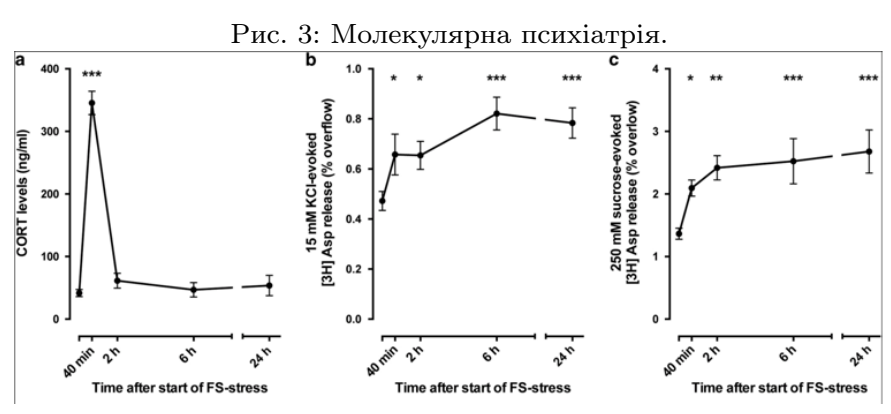

Результати дослідження 3 використанням футшок протоколу $<4>$.

і щільності дендритів: аномальне підвищення передачі нервового збудження є причиною дендритних атрофій у відповідних синапсах від початку дії стресу і аж до 14 днів після нього. Поточні результати узгоджуються 3 гіпотезою, що гострий стрес впливає на функцію i морфологію синапсів.

На відміну від хронічного стресу, довгострокові наслідки гострого стресу були мало або взагалі не досліджені досі. Традиційні дослідження хронічного стресу на гризунах просто розглядали кінцеву точку численних адаптацій, що виникають в процесі відповіді мозку і тіла на стрес, не часто звертаючись до найважливішого питання. Як система добирається до точки, де фізіологічні реакції на стрес перетворюються в неадаптивні, які можуть призводити до психопатології? Отримані результати доводять, що однієї травми достатньо, щоб викликати посттравматичний стресовий розлад у людей. Вивчення довгострокових результатів впливу гострого стресу в моделях гризунів, із спостереженням за їх поведінкою, функціональними і молекулярними змінами, дозволить ідентифікувати критичні "точки повороту"у відповідь на стрес і проллє світло на патофізіологію розладів, викликаних стресом. Розуміння детермінант довгострокових наслідків гострого стресу може допомогти виділити нейронні механізми i ефектори (органи або клітини, які активізуються у відповідь на стимул), які спрацьовують викривлено під час реакції на стрес.

Гострий стрес викликає стійку активацію збуджуючих синапсів в ПФК / ФК, принаймні на 24 години. Стрес-індуковані пластичні зміни в функціональних / структурних / молекулярних властивостях синапсів (зміна концентрації синапсину I) можуть вплинути на подальше функціонування синапсу (продовжена в часі стресова реакція, ПТСР). Не всі особи реагують однаковим чином на стимуляцію стресом. Пластичні зміни, які спостерігаються в цих випадках, можна умовно розділити на два типи: вразливі і стійкі (резистентні). В основу досліджень спрямованих на пошук прицільного лікування може лягти ідентифікація повороту та ключових критичних точок дихотомії у відповіді мозку на стрес (адаптивна / неадаптивна; вразливі проти стійких). 
Рис. 4: Нейроматриця.

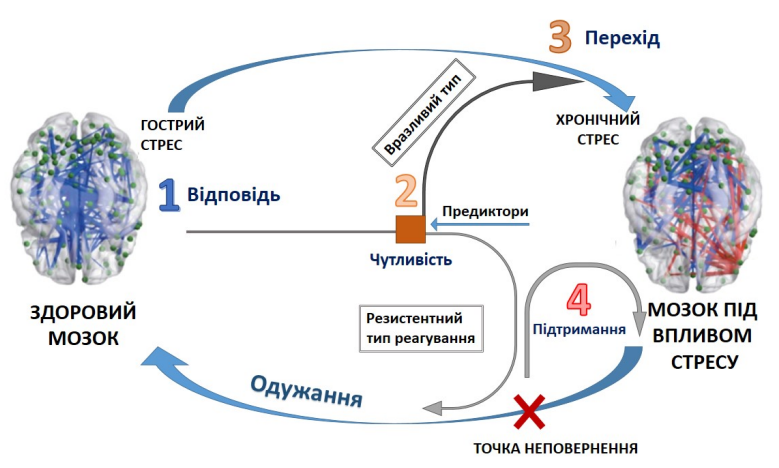

Зсув «вперед-назад» від здорового до стресового стану головного мозку.

\section{3. Динаміка змін в мозку під дією стресу}

Nuno Sousa, професор університету Міно (Португалія) в своїй доповіді «динаміка змін в мозку під дією стресу», підтримав важливість вивчення схильності індивіда і диференціації його типу відповіді на дію гострого стресу $<5>$. Наступний крок - визначити, чи буде сформований достатній патерн, щоб впоратися зі стресом і що змінюється в ланцюзі взаємодій і структурі мозку. Стресори можуть бути реальними чи уявними. Більше того, стрес-фактори не тільки суб'єктзалежні (атрибутивне значення), але і мають різну часову динаміку (повторювані, короткострокові або тривалі), можуть змінюватися за інтенсивністю (зокрема, в сприйнятті індивіда). Тобто, стрес-фактори можуть бути помірними і відносно нешкідливими або мати негайні та / або довгострокові наслідки для здоров'я суб'єкта. Більшість людей час від часу неминуче стикаються зі стресом. Проте, вкрай важливо підкреслити, що не завжди стрес є чимось «поганим» і / або шкідливим. Насправді, стрес має вирішальне значення для нашого власного виживання як виду, будучи нерозривно пов'язаним з еволюцією - виживанням шляхом адаптації. Всі тварини, навіть рослини, мають реакції на стрес.

Nuno Sousa запропонував динамічну робочу модель цілісного погляду на зрушення «вперед-назад» від здорового до стресового стану головного мозку. У цій робочій моделі, існують чотири незалежних кроки (хоча вони взаємодіють між собою): (1) відповідь, (2) чутливість, (3) перехід і (4) підтримання; ці кроки демонструють динаміку переходу від гострого до хронічного стресу (4). Найбільш важливо звернути увагу на визначення ключових вузлів хроніфікації процесу і «точок неповернення».

Реакція на стрес залежить від ряду факторів: час, індивідуальна мінливість, передбачуваність, керованість. Час розглядається не тільки як динаміка ефектів на головний мозок в залежності від тривалості впливу стресу, а ще і як особливості диригування мозком відповіді на стрес-фактори в різних станах. Інди- відуальна мінливість має важливе значення, вона відображає як різні люди по-різному реагують на стрес. Симптоми варіюють від тривожного та / або пригніченого настрою, гніву та / або дратівливості до травних або шкірних ускладнень або навіть імунної супресіі. Важливо відзначити, що існують значні відмінності в тому, як окремі суб'єкти справляються зі стресом. Ці відмінності $є$ найважливішими елементами неадекватної відповіді на стрес і впливають на психічне і фізичне здоров'я. Передбачуваність - реакція на стрес з часом еволюціонувала, щоб жорстко контролюватися і регулюватися. Іншими словами, якщо індивід багаторазово зіштовхується з одним і тим же стресором, організм зазвичай розвиває адаптивну реакцію. У значній кількості досліджень використовуються протоколи тривалого стресу, в завдання яких входить вимір відповіді на цей стресор, і здатність суб'єкта до нього адаптуватися. Четвертий фактор - керованість. Як показують роботи з різних лабораторій, контроль над стресором має вирішальне значення для встановлення його шкідливого впливу. Дослідження доводять, що тварини, які мають контроль над стресором, не виявляють серйозних ознак або симптомів стресу, і навпаки, безконтрольність ситуації викликає значну дезадаптацію.

Описані детермінанти індивідуальної сприйнятливості в різних проявах регулюють перехід реакції на стрес у хронічну форму або одужання (вразливість / резистентність) (рис. 4). Таким чином, моніторинг цих факторів має вирішальне значення для правильної інтерпретації наслідків стресу в головному мозку. У цьому випадку, основним завданням дослідження стала здатність визначити предиктори таких індивідуальних патернів реагування.

3 цією метою був проведений експеримент: порівняння даних, отриманих за допомогою функціонального МРТ (фМРТ), проводилося в групі контролю і групі дослідження (яка піддавалася дії стресу). У групі дослідження стрес впливав на активацію медіальної префронтальної кори, хвостатого ядра (цілеспрямована поведінка) і шкаралупи (putamen), разом вони являють собою неостріатум. Через 6 тижнів при повторному обстеженні фМРТ дослідники побачили аналогічні результати, що були різними для групи дослідження і контролю.

При структурних вимірах обсягу ГМ у кортикостріарній системі були виявлені зони, які після впливу стресу збільшуються в обсязі - путамен і орбітопрефронтальна кора (на рис. 5 відзначені помаранчевим кольором), і ділянки які зменшуються в розмірі (на рис. 5 відзначені синім кольором) - хвостате ядро і медіально-префронтальна кора. На рисунку 6 представлені дані обстежень фМРТ тієї ж вибірки пацієнтів на етапі відновлення після стресу, які демонструють наскільки кортико-стріарна система здатна до надзвичайної нейропластичності.

Інтеграція даних про локалізацію порушень структурних і функціональних зв'язків між різними зонами 
Рис. 5: Вплив стресу.
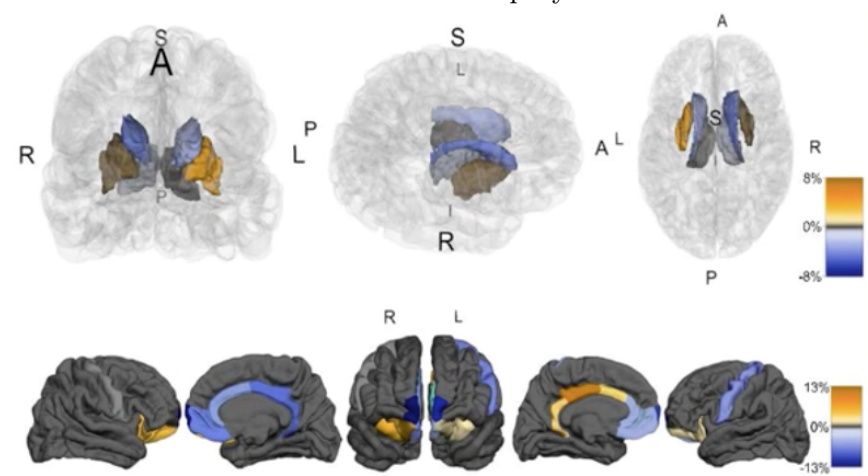

Помаранчевим кольором відмечені путамен та орбітопрефронтальна кора, які збільшується в об'ємі під дією стресу. Синім кольором - хвостате ядро та медіально-префронтальна кора, які зменшуються у об'ємі під дією стресу.

мозку дала можливість ученим відтворити і порівняти функціональний коннектом (карта нейронних з'єднань) контрольної групи і групи дослідження після впливу стресу за допомогою моделювання нейронних мереж (network modeling). Кластерний аналіз дозволив розділити групу обстеження на дві підгрупи: респондери 3 високим або низьким рівнем кортизолу. Повертаючись до питання чутливості до стресу, ці дві групи відповідають вразливому і резистентному типу реагування на стрес (рис.

\section{4. Роль окситоцину і нейропептида С в лікуван- ні стресових розладів}

Ми спробували знайти відповідь на це питання в презентаціях інших доповідачів. Наприклад, David A. Slattery (Frankfurt, Germany) в своїй доповіді підкреслив, що вивчення етіології розладів, викликаних дією стресу (зокрема, ПТСР та соціального тривожного розладу), на молекулярному рівні дозволить визначити детермінанти індивідуальної чутливості до стресу, розробити нове селективне і ефективне лікування. Попередні дослідження в області лікування даних розладів бачили мішенями вплив на моноамінергічні та ГАМКа рецептори. Доктор Slattery пропонує змістити увагу на нейропептиди, що, на його думку, є життєздатними новими кандидатами для фармакотерапії стресових розладів $<\underline{6}>$.

У чому перевага нейропептидів? Вони зосереджені в невеликій частини ГМ, але легко проникають в усі відділи через широко розповсюджену мережу рецепторів до них. Нейропептид С (НПС) - це амінокислотний пептид, який присутній у тварин усіх видів, він виробляється за допомогою нейронів в мигдалині, в основному глутаматергічними або позитивними клітинами CRF (кортикотропін-релізинг фактор). Дослідження на тваринах свідчать, що НПС пригнічує тривогу, апетит, викликає безсоння і гіперактивність, в тому
Рис. 6: Відновлення після впливу стресу.
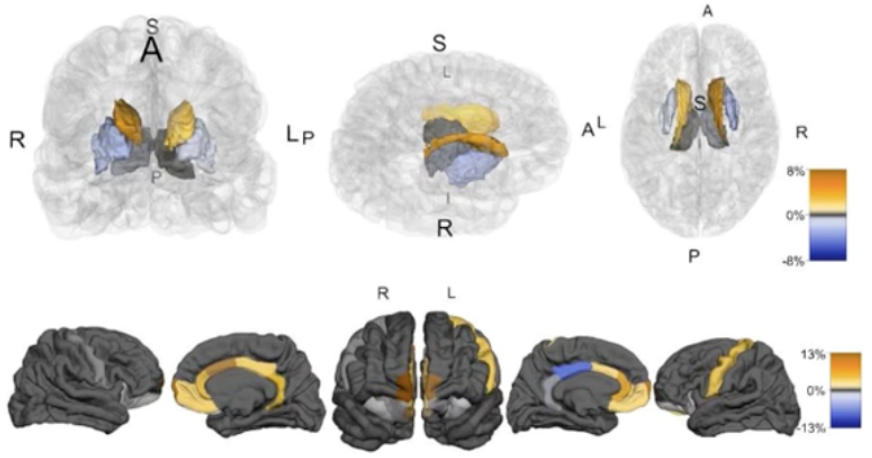

Представлені результати обстеження тієі ж вибірки пацієнтів, що і на рис. 5. Результати демонструють нейпропластичність кортико-стріарної системи у контексті відновлення після стресу.

числі гіперсексуальність, і грає важливу роль в гальмуванні обумовленого страху. Клінічні дослідження в 2002 році показали, що носії Т-алелей рецепторів нейропептіда C (різні форми одного і того ж гена, що розташовані в однакових ділянках гомологічних хромосом і визначають альтернативні варіанти розвитку однієї й тієі ж ознаки), пов'язані з підвищеним ризиком виникнення панічних розладів і надмірної інтерпретації страху. Однонуклеотидний поліморфізм (відмінність у послідовності ДНК розміром в один нуклеотид в геномі, що виникає в результаті точкових мутацій) рецепторів нейропептида C (NPSR1) у людини викликає заміна амінокислоти аспарагін на ізолейцин, що призводить до десятиразового збільшення активності рецепторів, не змінюючи загальний рівень їх експресіі. Доклінічні дослідження на тваринах вказують, що введення нейропептида С безпосередньо в центральну нервову систему викликає сильний анксіолітичний і збудливий ефект, а введення всередину мигдалини призводить до зниження тривоги і згасання сигнального і контекстного страху у гризунів. У людей навпаки: якщо система нейропептида C активна, ми спостерігаємо панічний розлад. Цю невідповідність можна пояснити тим, що всі доклінічні дослідження проводилися на нормальних тваринах (ніяких додаткових маніпуляцій, що стимулюють страх, з ними не проводили). Відповідно була створена нова модель, коли у тварини викликали тривожний стан, впливаючи на неї стресом. В ході дослідження (лабіринти, обумовлювання страху звуковими сигналами) були виділені декілька груп тварин в залежності від провідної поведінки. До першої групи віднесли тих мишей чи пацюків, які більшу частину часу трималися в конструкції близько до безпечних стінок - поведінка пов'язана з високою тривогою (high anxiety-related behavior, НАВ); їх можливість активно справлятися зі стресом, так само як і можливість пригнічувати страх, була знижена, а експресія страху перебільшена. Друга група характеризувалася поведінкою з низькою тривогою (low anxiety-related behavior, LAB) гризуни набагато частіше виходили на відкриті незахищені ділянки 
в лабіринтах. Далі гризунів схрещували виключно всередині своїх груп (HAB і LAB). На питання, чи має цей поділ в поведінці гризунів кореляцію зі змінами в системі нейропептида С, вчені відповіли однозначно. В категорії гризунів з високою поведінковою тривогою був виявлений один загальний однонуклеотидний поліморфізм, асоційований з поверхневою експресією рецепторів (NPSR1), який пошкодив стабільність мРНK, структуру і синтез білка, і вніс зміни в активність промотерів in vitro i експресії in vivo. Вчені побачили, що центральне введення нейропептида С ефективно справляється з тривогою і гасить страх у гризунів з високою поведінкової тривогою (НАВ), тоді як анксіолітичний ефект на класичні транквілізатори (діазепам) у цих мишей був відсутній.

Таким чином, була протестована гіпотеза про те, що селективне розмноження серед груп гризунів з низькою і високою поведінковою тривожністю призводить до генетичних, експресивних і функціональних відмінностей в системі нейропептид C - рецептор (NPS-NPSR1), а введення нейропептида $\mathrm{C}$ має анксіолітичний ефект в групі з високою поведінкової тривогою.

Окситоцин також становить інтерес як альтернативне лікування тривожних розладів, що більшою мірою впливає на соціальну поведінку. Довгий час він вважався «материнським гормоном», але в 1990-х - дослідження показали, що окситоцин здатний знижувати тривогу і підвищувати соціальну поведінку (турбота про потомство, сексуальний інстинкт, соціальна пам'ять). Але чи має він вплив на соціальну тривогу або страх? У преклінічних дослідженнях введення окситоцину ефективно знижувало соціально-обумовлений страх (social fear conditioning) і соціальне уникання, в тій же мірі, що і введення бензодіазепіну або тривале призначення пароксетину. Але на відміну від нейропептида $\mathrm{C}$, він не впливав на вираженість тривоги i страху, обумовленого звуковими сигналами (cue fear conditioning); нейропептид С був ефективний в обох ситуаціях. Слід зазначити, що окситоцин в низьких дозах не впливав ні на поведінку, ні на фізіологію; свою ефективність він демонструє тільки при призначенні у високих дозах $[<7>]$. Огляди тривалого призначення окситоцину показують, що його анксіолітична дію відрізняється в залежності від статі. Для жіночої статі ефект більш виражений, але необхідні подальші дослідження в цьому напрямку $<\underline{8}>$. Окситоцин. введений до початку дії стресу, уповільнює внутрішньоклітинне збільшення вироблення кортикотропін-релізинг фактору і кортизолу; тобто, надалі він знижує інтенсивність реакції активації, орієнтування, тривоги, страху, неспокою, напруги. Таким чином, окситоцин і нейропептид С представляють собою перспективних кандидатів у лікуванні тривожних розладів.

\section{5. Нові підходи в профілактиці i лікуванні ПТСР}

В рамках симпозіуму «нові стратегії і мішені в лікуванні посттравматичного стресового розладу», головами якого були Eric Vermetten i Joseph Zohar, слухачі познайомилися з низкою практичних доповідей. Lior Carmi (Тель-Авів, Ізраїль) представив концепцію «золотих годин» (golden hours) в лікуванні ПТСР $[<9>]$. Відмінність від інших тривожних захворювань і унікальність цього розладу в тому, що він має чіткий початок - точку відліку, а конкретно - час впливу стресфактора, після якого настає значне погіршення стану індивіда. Чи може психіатр запобігти розвитку посттравматичного стресового розладу? Давайте подумаємо, які існують інтервенції і стратегії лікування гострого стресового розладу, що спрямовані на профілактику ПТСР, а які втручання можуть погіршити симптоматику.

Одним 3 ключових симптомів ПТСР, крім наявності травматичної подї в анамнезі, є повторне переживання, наряду з уникаючою поведінкою, симптомами оніміння або заціпеніння і підвищеною збудливістю. Симптоми повторного переживання або «травматична пам'ять» включають в себе: нав'язливі спогади, образи і думки, що вторгаються в життя, нав'язливі кошмарні сни про травматичну подію. Ці симптоми сприймаються як «реальність» (ілюзії, галюцинації, «флешбеки», дисоціації) і призводять до інтенсивних психологічних і фізіологічних реакцій. Минуле завжди переслідує в теперішньому: людина неначе проживає травму знову. Спостерігаючи за процесами, які лежать в основі формування пам'яті на подію, відмітимо, що репрезентація події з короткострокової пам'яті за допомогою процесу консолідації закріплюється в довгостроковій пам'яті. Має місце і зворотний процес - реконсолідація. Консолідація або інтеграція нового досвіду (нестабільні спогади) в довгострокову (стабільну) пам'ять вимагає синтезу протеїнів (білкових молекул) в клітинах мигдалини $<10>$. А що відбудеться, якщо перешкоджати процесу консолідації пам'яті? Чи буде амнезія на травматичні події скорочувати або збільшувати ризик ПТСР у пацієнтів з травматичним ураженням ГМ? Проспективне дослідження показало, що у лише $6 \%$ пацієнтів без пам'яті про травматичні події і амнезією на 24 години після травми були виявлені симптоми ПТСР через 6 місяців в порівнянні з 23\% пацієнтів зі збереженою пам'яттю про травму $<11>$. Амнезія і фармакологічне руйнування травматичної пам'яті може бути ефективним у зниженні ризику виникнення ПТСР. Таким чином, впливаючи на перехід репрезентація події з короткострокової пам'яті в довгострокову, ми можемо сприяти профілактиці ПТСР. Відомо, що консолідація в гіпокампі відбувається в основному вночі, під час сну, тому об'єктом майбутніх досліджень може стати кореляція депривації сну в першу ніч після травми і ризику виникнення ПТСР. 
Як вже обговорювалося вище, в гостру фазу стресу відбувається активація гіпоталамо-гіпофізарнонадниркової вісі, медіатором якої є кортизол. Виходячи з доклінічних досліджень, ми знаємо, що в залежності від типу реакції на стрес респонденти поділяються на дві категорії, рівень кортизолу яких буде підвищений або понижений, тривога буде високою або зниженою. Може скластися враження, що резистентний тип реакції або відсутність тривоги у відповідь на травматичну подію - це добре, але в дійсності це не так. Адекватна відповідь гіпоталамо-гіпофізарно-надниркової вісі i, як наслідок, високий рівень кортизолу - це загальний адаптаційний синдром; він є природним способом організму пережити стрес. I навпаки, низький рівень кортизолу - це явище, яке призводить до патологічної реакції на стрес; воно є наслідком дефекту гіпоталамусу. Ця гіпотеза була підтверджена в преклінічних дослідженнях: ін'єкція високих доз гідрокортизону була ефективною, тільки якщо застосовувалася в перші 6 годин («золоті години») після травматичної події. 100-140 мг препарату може знизити рівень виникнення ПТСР 3 $60 \%$ до 16\%. Якщо знижений рівень кортизолу асоційований з ПТСР, яким буде ефект призначення бензодіазепінів (діазепам, гідазепам)? Бензодіазепіни, підсилюючи ефект гамма-аміномасляної кислоти на ГАМКа рецептори (ідентично діє алкоголь) викликають седативний, гіпнотичний і анксіолітичний ефекти, фактично блокуючи роботу гіпоталамо-гіпофізарно-надниркової вісі. Медична спільнота виступає проти раннього призначення бензодіазепінів і вважає, що вони заважають проходженню природної адаптаційної реакції організму. Дослідження підкріплюють ці дані про те, що раннє призначення бензодіазепінів збільшує ризик розвитку ПТСР. Навпаки, дослідження на гризунах показало, що ряд препаратів, призначених одразу ж після впливу стресу, сприяли зменшенню симптомів ПТСР. Виділяють наступні групи препаратів за механізмом дії: ті, що блокують процес консолідації (анізоміцін), доповнюють нестачу кортизолу (гідрокортизон у високих дозах, окситоцин), антидепресанти (агомелатин, есциталопрам, сертралін). Зворотний ефект мали: кортизол в малих дозах, альпразолам, кетамін, алкоголь.

I наостанок, важливим фактором ризику для розвитку нейропсихічних розладів все ще залишається вплив стресових подій на функції мозку і тіла. Різні інтервенції можуть мати різні вікна можливостей. Відповідно, одні і ті ж інтервенції можуть зцілити або нанести шкідливий ефект залежно від зміни часу призначення. Вплив стресу відбувається в декількох вимірах одночасно (анатомія, електрофізіологія, поведінка, соціальна інтеракція). Розуміння взаємодій між стресом, тканиною мозку і соціальною поведінкою допомогло прокласти шлях до розробки майбутніх стратегій лікування.

\section{References}

1. Soetanto A, Wilson R, Talbot K, Un A, Schneider J, Sobiesk M, Kelly J, Leurgans S, Bennett D, Arnold S. Association of anxiety and depression with microtubule-associated protein $2-$ and synaptopodin-immunolabeled dendrite and spine densities in hippocampal ca3 of older humans. Archives of General Psychiatry 2010-may;67(5):448-57. doi 10.1001/archgenpsychiatry. 2010.48

2. Sheline Y, Wang P, Gado M, Csernansky J, Vannier M. Hippocampal atrophy in recurrent major depression. Proceedings of the National Academy of Sciences 1996-apr;93(9):3908-13.

3. Popoli M. Stress and antidepressants: time-dependent changes in synaptic function and brain architecture. In: Proc. of 29th ECNP Congress. ECNP Congress; Austria, Vienna: ECNP; 2016:

4. Musazzi L, Treccani G, Mallei A, Popoli M. The action of antidepressants on the glutamate system: Regulation of glutamate release and glutamate receptors. Biological Psychiatry 2013jun;73(12):1180-8. doi $10.1016 /$ j.biopsych. 2012.11.009

5. Sousa N. The temporal dynamics in the stressed brain. In: Proc. of 29th ECNP Congress. ECNP Congress; Austria, Vienna: ECNP; 2016:.

6. Slattery D. Oxytocin in general anxiety and social fear: A translational approach. In: Proc. of 29th ECNP Congress. ECNP Congress; Austria, Vienna: ECNP; 2016:.

7. Peters S, Slattery D, Uschold-Schmidt N, Reber S, Neumann I. Dose-dependent effects of chronic central infusion of oxytocin on anxiety, oxytocin receptor binding and stress-related parameters in mice. Psychoneuroendocrinology 2014-apr;42:225-36. doi 10 . 1016/j.psyneuen.2014.01.021

8. Neumann I, Slattery D. Oxytocin in general anxiety and social fear: A translational approach. Biological Psychiatry 2016feb;79(3):213-21. doi 10.1016/j.biopsych.2015.06.004

9. Carmi L. Clinical intervention in golden hours - state of the art. In: Proc. of 29th ECNP Congress. ECNP Congress; Austria, Vienna: ECNP; 2016:.

10. Nader K, Schafe G, Doux J. Fear memories require protein synthesis in the amygdala for reconsolidation after retrieval. Nature 2000-aug;406(6797):722-6. doi 10.1038/35021052

11. Gil S, Caspi Y, Ben-Ari I, Koren D, Klein E. Does memory of a traumatic event increase the risk for posttraumatic stress disorder in patients with traumatic brain injury? a prospective study. American Journal of Psychiatry 2005-may;165(5):963-9. doi 10.1176/appi.ajp.162.5.963 